\title{
A perspective of chemical treatment for cyanobacteria control toward sustainable freshwater development
}

\author{
Jae-Hoon Huh ${ }^{\mathbf{1}^{\dagger}}$, Ji-Whan $\mathrm{Ahn}^{2}$ \\ ${ }^{1}$ Korea Institute of Limestone and Advanced Materials (KILAM), Chungbuk 27003, Republic of Korea \\ ${ }^{2}$ Carbon Resource Recycling Appropriate Technology Center, Korea Institute of Geoscience and Mineral Resources (KIGAM), Daejeon 34232, \\ Republic of Korea
}

\begin{abstract}
One of the most threatening consequences of eutrophic freshwater reservoirs is algal blooming which typically occur after the long a mega drought or/and irregular rainfall under influence of climate change. The long-term experiences of chemical treatment are known as a most practical effort to reduce health concerns from human exposure of harmful cyanobacteria as well as to preserve ultimate freshwater resources. Even though these conventional chemical treatment methods do not completely solve the algal residue problem in water treatment plant or directly in the water bodies, they still have big advantages as fast and efficient removal process of cyanobacteria due to cheaper, easier to manage. This review summarizes their chemical treatment scenarios of the representative coagulants, pre-oxidants and algaecides composed to chemical compounds which immediately may help to manage severe cyanobacteria blooms in the summer seasons.
\end{abstract}

Keywords: Algae, Chemical treatment, Cyanobacteria, Eutrophication, Freshwater

\section{Introduction}

As a result of human activity, the increases in the accumulation of greenhouse gases in the atmosphere has contributed to severe global warming while industrial engineering developments have accelerated our rapid transition of the modern age [1, 2].

Since the distribution of precipitation is very uneven and the rate of evaporation varies a great deal, depending on the temperature and relative humidity, natural variations caused by climate change are main reason that lakes and rivers over the world are ephemeral features of the landscape. The ecosystem in these freshwater reservoirs are vital resources for aquatic wildlife and human needs and play a significant role in supplying drinking water, fishing, and recreation as well as maintaining a regional ecological balance and sustainable socioeconomic development [3-5]. Undoubtedly, the growing world population is inextricably linked with sustainable freshwater development throughout world which also places considerable pressure on the requirements of fresh water needed for agriculture, energy, and industry. Many countries still face the challenges of eliminating poverty, promoting economic growth, ensuring health and sanitation, preventing curbing land degrada- tion and pollution, and advancing rural and urban development [6]. Therefore, the current generation is required to be responsible for freshwater conservation and leave behind a sustainable inheritance to future generations [7-9].

Mountainous countries (i.e. South Korea) can formulate action plans for water storage, especially a great deal of summer rainfall for freshwater resources through the construction of dams or weirs. Specifically, the four major river restoration projects in South Korea were begun to address the significant environmental challenges faced by the Han, Nakdong, Geum and Yeongsan rivers. However, since then those water bodies have become breeding ground for the cyanobacteria because there was not enough consideration for the aquatic ecosystems. The complex interactions of sufficient sunlight, high levels of nutrients in the rivers, and slower flow speeds are likely responsible for the larger and more frequent algal outbreaks [10-14].

The recent chemical treatment method for acute reduction of cyanobacteria using inorganic coagulants can be classified by several criteria according to: (1) applied site (surface water, water treatment plant, sediment); (2) purpose (decrease of nutrient concentration, inhibition of cyanobacteria toxin and unpleasant odor).
This is an Open Access article distributed under the terms of the Creative Commons Attribution Non-Commercial License (http://creativecommons.org/licenses/by-nc/3.0/) which permits unrestricted non-commercial use, distribution, and reproduction in any medium, provided the original work is properly cited.
Received December 21, 2016 Accepted February 14, 2017

${ }^{\dagger}$ Corresponding author

Email: houjh@naver.com

Tel: +82-43-422-2194 Fax: +82-43-422-5581 


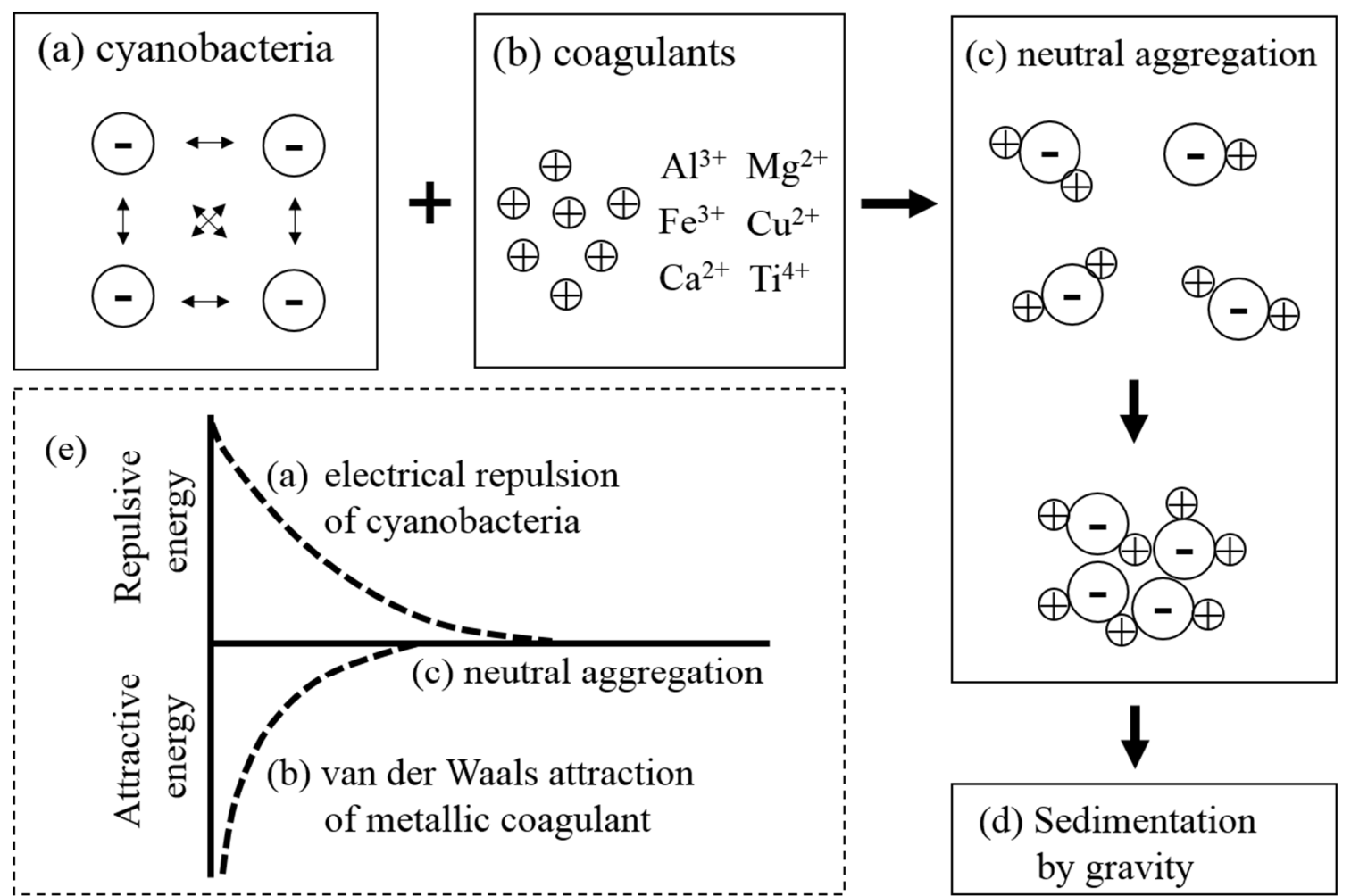

Fig. 1. Coagulation and sedimentation scenario of cyanobacteria using inorganic coagulant: (a) stable cyanobacteria cells (b) metallic coagulants (c) neutral aggregation (d) sedimentation by gravity and (e) energy diagram of cyanobacteria in coagulation process.

In view of the primary role, we focus chemical treatments using inorganic coagulants containing pre-oxidants and algaecides to reduce cell counts of cyanobacteria in the surface freshwater and water treatment plant. For the easy understanding of concept with cyanobacteria control, a scenario of a representative chemical treatment process using metallic coagulants for cyanobacteria control is illustrated in Fig. 1.

\section{Algae and Eutrophication in Freshwater}

Eutrophication is aquatic ecosystem response to addition of artificial or national nutrients containing mainly phosphorous and nitrogen elements through detergents, fertilizers, and sewage. The trophic status of lakes describes the relationship between the nutrient status of a lake and the growth of organic matter in the lake. Eutrophication is the process of change from one trophic state to a higher trophic state by the addition of nutrients. Agriculture is a major factor in the eutrophication of surface water. Two of the major nutrients in freshwater, nitrogen $(\mathrm{N})$, needed for protein synthesis, and phosphorus (P), needed for DNA, RNA, and energy transfer, are both required to support aquatic plant growth and are the key limiting nutrients in most aquatic and terrestrial ecosystems [10]. Human activity has profoundly altered the global biogeochemical cycle of $\mathrm{N}$. The global production of agricultural fertilizers increased from less than 10 million metric tonnes of $\mathrm{N}$ in 1950 to a prediction of more than 135 million metric tonnes of $\mathrm{N}$ by 2030. $\mathrm{P}$ inputs from fertilizers and manures greatly exceed $\mathrm{P}$ outputs in farm produce, and $\mathrm{P}$ is, thus, accumulating yearly in the soil. The loading of $\mathrm{N}$ and $\mathrm{P}$ into the world's rivers, lakes, and oceans is very strongly influenced by human population densities, the population densities of livestock, and land use [15]. Note that water quality has declined dramatically in the past 50 years, primarily because of the increase of $\mathrm{N}$ and $\mathrm{P}$ eutrophication from human or animal manure effluents, as well as from municipal and industrial wastewater. The increase in eutrophication is most likely due to an increase in nutrient input from these sources, as a result of increased human activities in the freshwater reservoir surroundings [16-18]. Algal production during the summer can be activated by $\mathrm{N}$ and $\mathrm{P}$ nutrients in the surface water so appropriate coagulators can be used as process to return to the soil with the algae containing nutrients for plant growth.

Electrostatic repulsion force make possible to long term stable state with constant distance between suspended algae cells; otherwise, the collision of particles would result in attachment as result of the universal van der Waals forces of attraction. For the growth of the algae, the most important factors include light, temperature, the chemical composition, and the acidity or alkalinity of the freshwater. Shen et al. reported that algae density drops ten times when the temperature of the surface water drops from $34^{\circ} \mathrm{C}$ to $27^{\circ} \mathrm{C}$. This partially explains why outbreaks of algal blooms usually occur in the summer when water temperatures are high, water depth is low and water nutrient concentrations are high. 
Therefore, in summer when the temperature is relatively high, it is particularly important to remove algae from drinking water sources [19].

\section{Cyanobacteria of Major Harmful Algae}

\subsection{Freshwater Reservoirs}

Toxin-producing cyanobacteria (blue-green algae) are the major harmful algal group in freshwater environments and are recognized as a rapidly expanding global problem that threatens human and ecosystem health. Table 1 shows cyanobacterial toxins that produce human health effects when they are taken into the human body over short and long-term periods [20-28]. Blooms of the cyanobacteria are ubiquitous phenomena in eutrophic lakes and reservoirs in many countries around the world from investigations into physicochemical and biological water quality [29, 30]. The thick scums production is a primary factor of water quality deterioration which includes foul odors and tastes because it generate deoxygenation of bottom waters, toxicity dissociation concerns, fish breathing trouble, and aquatic ecosystem destruction. Table 2 lists the cell counts of cyanobacteria species in the Deachung Reservoir which appeared during the summer season of 2003 [31]. In the algal outbreak period, safe drinking water quality is one of the most important issues in public health due to the presence of cyanobacteria in the drinking water supplies poses a hazard to humans [32-39]. A real time monitoring system is one of most critical methodology in water resource management through rapid and accurate recognition and classification of algae and cyanobacteria which cause uncomfortable tastes and odors filter clogging, and deterioration of the drinking water quality $[40,41]$. A higher frequency of toxic cyanobacteria blooms in the future is likely to be attributed to complex direct function of water parameters (e.g., temperature, nutrient, light, conductivity) and complex indirect function on their predators and competitors as illustrated in Fig. 2 [42]. Chemical treatment using inorganic coagulants for rapid aggregation of cyanobacteria cell in freshwater reservoirs can be achieved in conjunction with subsequent sedimentation or floatation. While floatation tends to achieve faster rates of separation and more concentrated product stream, it is required further treatment process to move the floating product. On the other hand, coagulation-sedimentation process is often used as the low cost treatment technique in economic analysis.

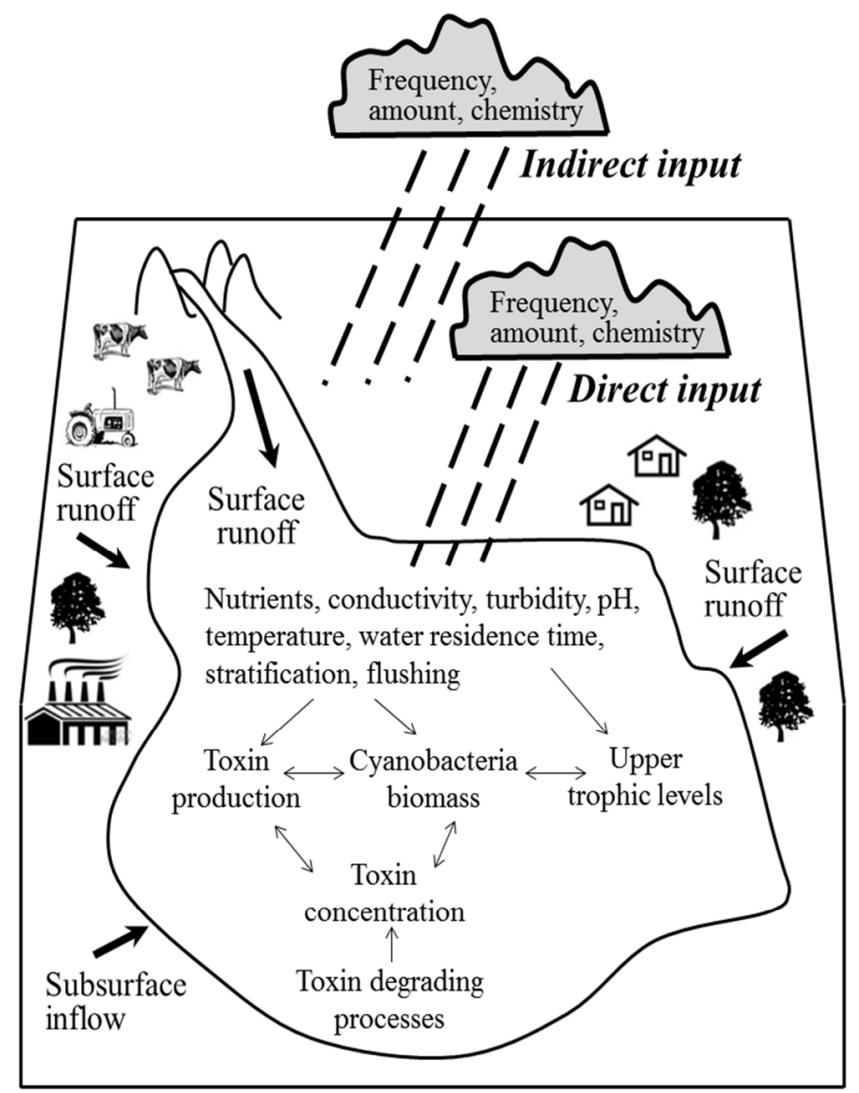

Fig. 2. A conceptual diagram showing the different pathways of water flowing into inland waterbodies during and after rainfall events, and the physical, chemical and biological parameters that potentially affect cyanobacterial bloom dynamics, toxin production, and total toxin concentration in an inland waterbody. [42]

Table 1. Short and Long Term Health Effect of Cyanobacterial Toxins When They Are Taken into the Human Body [20]

\begin{tabular}{|c|c|c|}
\hline Toxin & Short-term health effects & Long-term health effects \\
\hline Mycrocystins [21] & $\begin{array}{l}\text { Gastrointestinal, liver inflammation, hemorrhage, pneumonia, } \\
\text { dermatitis and liver failure leading to death }\end{array}$ & $\begin{array}{l}\text { Tumor promoter, liver failure } \\
\text { leading to death }\end{array}$ \\
\hline Nodularins [22] & Similar to Microcystins & Similar to Microcystins \\
\hline Saxitoxins [23] & $\begin{array}{l}\text { Tingling, burning, numbness, drowsiness, incoherent speech, } \\
\text { respiratory paralysis leading to death }\end{array}$ & Unknown \\
\hline Anatoxins [24] & $\begin{array}{l}\text { Tingling, burning, numbness, dowsiness, incoherent speech, } \\
\text { respiratory paralysis leading to death }\end{array}$ & Cardiac arrhythmia leading to death \\
\hline Cylindrospermopsin [25] & $\begin{array}{c}\text { Gastrointestinal, liver inflammation, hemorrhage, pneumonia, and } \\
\text { dermatitis }\end{array}$ & $\begin{array}{l}\text { Malaise, anorexia, liver failure } \\
\text { leading to death }\end{array}$ \\
\hline Lipopolysaccharide [26] & Gastrointestinal, dermatitis & Unknown \\
\hline Lyngbyatoxins [27] & Dermatitis & Skin tumors, unknown \\
\hline BMAA [28] & & $\begin{array}{c}\text { Potential link to neurodegenerative } \\
\text { diseases }\end{array}$ \\
\hline
\end{tabular}


Table 2. The Cell Counts of Cyanobacterial Algal Blooms Occurring in Daechung Lake in the Summer Season, South Korea, 2003 [31]

\begin{tabular}{c|cccc}
\hline $\begin{array}{c}\text { Cell count } \\
\text { / Sampling date }\end{array}$ & $\mathbf{8} / \mathbf{1 9}$ & $\mathbf{8} / \mathbf{2 6}$ & $\mathbf{9 / 2}$ & $\mathbf{9 / 9}$ \\
\hline Cyanobacteria (\%) & 98.6 & 95.2 & 95.8 & 74.2 \\
Phormidium (No./mL) & 0 & 0 & 0 & 375 \\
Planktothrix (No./mL) & 40,250 & 18,313 & 44,125 & 750 \\
Microcystis (No./mL) & 9,375 & 7,500 & 28,125 & 406 \\
Anabaena (No./mL) & 0 & 0 & 83 & 113 \\
Chroococcus (No./mL) & 0 & 0 & 0 & 306 \\
\hline
\end{tabular}

\subsection{Water Treatment Plant}

World Health Organization (WHO) has published a provisional guideline value of $1.0 \mu \mathrm{g}$ Microcystin (MC)-LR/l as the toxicity of cyanobacteria toxins in drinking water [43]. In practice, due to the small dimension and the low specific gravity of cyanobacteria, a single conventional process for cyanobacteria control is extremely difficult, so it is necessary to strengthen the use of combined conventional treatment processes. A most classical process in US water plants for the removal of suspended solids containing cyanobacteria residue in drinking water consists of five separate steps: 1) Coagulation, 2) Flocculation, 3) Sedimentation, 4) Filtration, and 5) Disinfection [44]. Coagulation is the process of decreasing or neutralizing the electric charge of suspended particles containing cyanobacteria with negative zeta potential. Similar electric charges on small particles in water cause the particles to naturally repel each other and hold the small, colloidal particles apart and keep them in suspension. The coagulation/flocculation process neutralizes or reduces the negative charge on the particles. This allows the van der Waals force of attraction to encourage the initial aggregation of colloidal and finely suspended materials to form microfloc. Flocculation is the process of bringing together the microfloc particles to form large agglomerations by either physically mixing them or through the binding action of flocculants. Suitable chemicals in the coagulation process are added to the initial influent wastewater stream, which is stirred and intensively mixed at a high speed. The influent wastewater in the flocculation process is only moderately stirred in order to form large flocs, which are easily settled out. The following factors should be taken into consideration for selecting the most appropriate coagulant/flocculant aid: 1) The effectiveness of removing phosphorus, 2) Cost and the reliability of supply, 3) Sludge considerations, both volume and characteristics, 4) Compatibility with other upstream or downstream treatment processes, 5) Environmental effects, 6) Labor and equipment requirements for storage, feeding, and handling [44].

In drinking water treatment, conventional coagulation is still the main treatment process for algal removal which results in the repeated collision and attachment of cells, forming progressively larger agglomerates that quickly settle. The inorganic particles usually originate from natural or anthropogenic sources and inhibit algal growth by attenuating light and limiting photosynthesis. Besides scattering and adsorbing solar radiation, suspended solids can also act as an adhesion surface.

\section{Conventional Chemical Treatment}

\subsection{Preoxidants}

Peroxidation is deemed effective in promoting the coagulation of algal cells and is widely used in drinking water treatment. Peroxidation chemical includes ozone, chlorine, chlorine dioxide, permanganate, or ferrate. The effects of disinfection and inactivation on the algae cells cause the changes of the zeta potential due to promote their aggregation. Peroxidation by permanganate also generates manganese dioxides in situ, which can adhere to the cells and promote their settling. However, peroxidation by chlorine $(\mathrm{NaOCl})$ or chlorine dioxide $\left(\mathrm{ClO}_{2}\right)$ forms undesirable disinfection byproducts such as chlorinated organics, chlorate, and chlorite. Ozone, chlorine, or ferrate can induce release of cyanobacteria toxins. Especially, ozone and permanganate are the most effective oxidants in promoting coagulation, so they are widely used in water treatment. Peroxidation can improve cyanobacteria coagulation to reduce the these cell counts but some of them result in taste- and odor occurrences due to higher oxidation strength [45-50].

\subsection{Algaecide}

To control the massive growth of algae in lakes and reservoirs, copper sulfate $\left(\mathrm{CuSO}_{4} \cdot 5 \mathrm{H}_{2} \mathrm{O}\right)$ has been the most widely used as substance for the control of undesirable algal growth for more than 110 years [51-54]. Single additions of copper sulfate do not effect a permanent reduction in algal abundances and repeated additions are needed to keep populations under control. Eventually copper is trace element that is an essential component of the biochemical functions of photosynthetic organisms. However, it can affect electron transport through photosystem and modify or inhibit fundamental enzymatic activities. Especially, in excessive concentrations of copper sulfate can promote the release of toxic Microcystin compounds because they affect physiological stress and cell membrane damage of cyanobacteria by great algaecide strength. Also, copper precipitates out of the water column or sorbs to suspended solids and accumulates in bottom sediments. Copper toxicity has also been the subject of many studies on freshwater algae and cyanobacteria species and copper bioavailability is related to its speciation, which is most likely relating to $\mathrm{pH}$, redox potential, alkalinity, and organic and inorganic ligand concentrations. Therefore, for the potential impacts of copper sulfate additions on lake ecosystems might need to anticipate future environmental issues [55-57].

\subsection{Inorganic Coagulants}

\subsubsection{Clay}

Many countries (US, Australia, Sweden, Japan, South Korea) have been known to use clay coagulants to remove algae [58-61]. In a 1996 report, workers in South Korea dispersed approximately 60,000 tons of dry yellow loess (a kaolinite-bearing sediment) that removal rates of specific algal blooms were calculated at $90 \%$ to $99 \%$ [61]. Fig. 3 shows the appearance of various kinds of algal cell surface that clay is adhered on algae cells by coagulation process [60]. Most representative clay has been Ca-montmor- 
illonite, kaolinite, sericite, and illite as shown in Table 3 [62-64] Clay minerals form sheet-like particles or platelets with a wide range of particle sizes from tens of angstroms to millimeters and their inherent properties also make them chemically active and adsorptive, thereby leading to a variety of uses as absorbent and catalyst products. Fig. 4 illustrates that in clay minerals, the active sites may arise from (1) broken edge sites and exposed surface aluminol and silanol groups, (2) isomorphic substitutions, (3) exchangeable cations, (4) hydrophobic silanol surfaces, (5) hydration shells of exchangeable cations, and (6) hydrophobic sites on adsorbed organic molecules [65]. The elements of silica, iron, aluminum, and magnesium can bridge linking algal cells, and

Table 3. The Chemical Composition, Diameter, and Specific Area of Clays: Kaolinite, Sericite, Illite and Montmorillonite [62-64]

\begin{tabular}{|c|c|c|c|c|}
\hline Chemicals & Kaolinite (\%) & Sericite (\%) & Illite (\%) & Montmorillonite (\%) \\
\hline $\mathrm{SiO}_{2}$ & 44.53 & 47.56 & 54.09 & 55.39 \\
\hline $\mathrm{Al}_{2} \mathrm{O}_{3}$ & 39.15 & 29.68 & 26.3 & 19.91 \\
\hline $\mathrm{TiO}_{2}$ & 0.21 & 0.15 & 0.68 & 0.14 \\
\hline $\mathrm{Fe}_{2} \mathrm{O}_{3}$ & 0.03 & 2.53 & 1.5 & 1.57 \\
\hline $\mathrm{FeO}$ & 0.01 & 1.25 & 1.49 & 0.37 \\
\hline $\mathrm{MnO}$ & N.D. & 0.04 & - & 0.01 \\
\hline $\mathrm{MgO}$ & 0.05 & 1.10 & 2.00 & 3.4 \\
\hline $\mathrm{CaO}$ & 0.07 & 1.83 & 0.49 & 0.52 \\
\hline $\mathrm{Na}_{2} \mathrm{O}$ & 0.05 & 0.13 & 0.22 & 3.37 \\
\hline $\mathrm{K}_{2} \mathrm{O}$ & 0.03 & 8.98 & 6.87 & 0.07 \\
\hline $\mathrm{P}_{2} \mathrm{O}_{5}$ & 0.19 & 0.12 & - & 0.04 \\
\hline $\mathrm{H}_{2} \mathrm{O}(+)$ & 14.37 & 4.82 & 6.89 & 6.37 \\
\hline $\mathrm{H}_{2} \mathrm{O}(-)$ & 0.98 & 0.44 & 1.32 & 8.73 \\
\hline $\mathrm{CO}_{2}$ & 0.21 & 1.19 & 5.79 & 0.45 \\
\hline Diameter $(\mu \mathrm{m})$ & $0.3-3.0$ & $0.1-2.0$ & & $0.1-1.0$ \\
\hline Specific area $\left(\mathrm{m}^{2} / \mathrm{g}\right)$ & $10-20$ & $60-100$ & & 800 \\
\hline
\end{tabular}
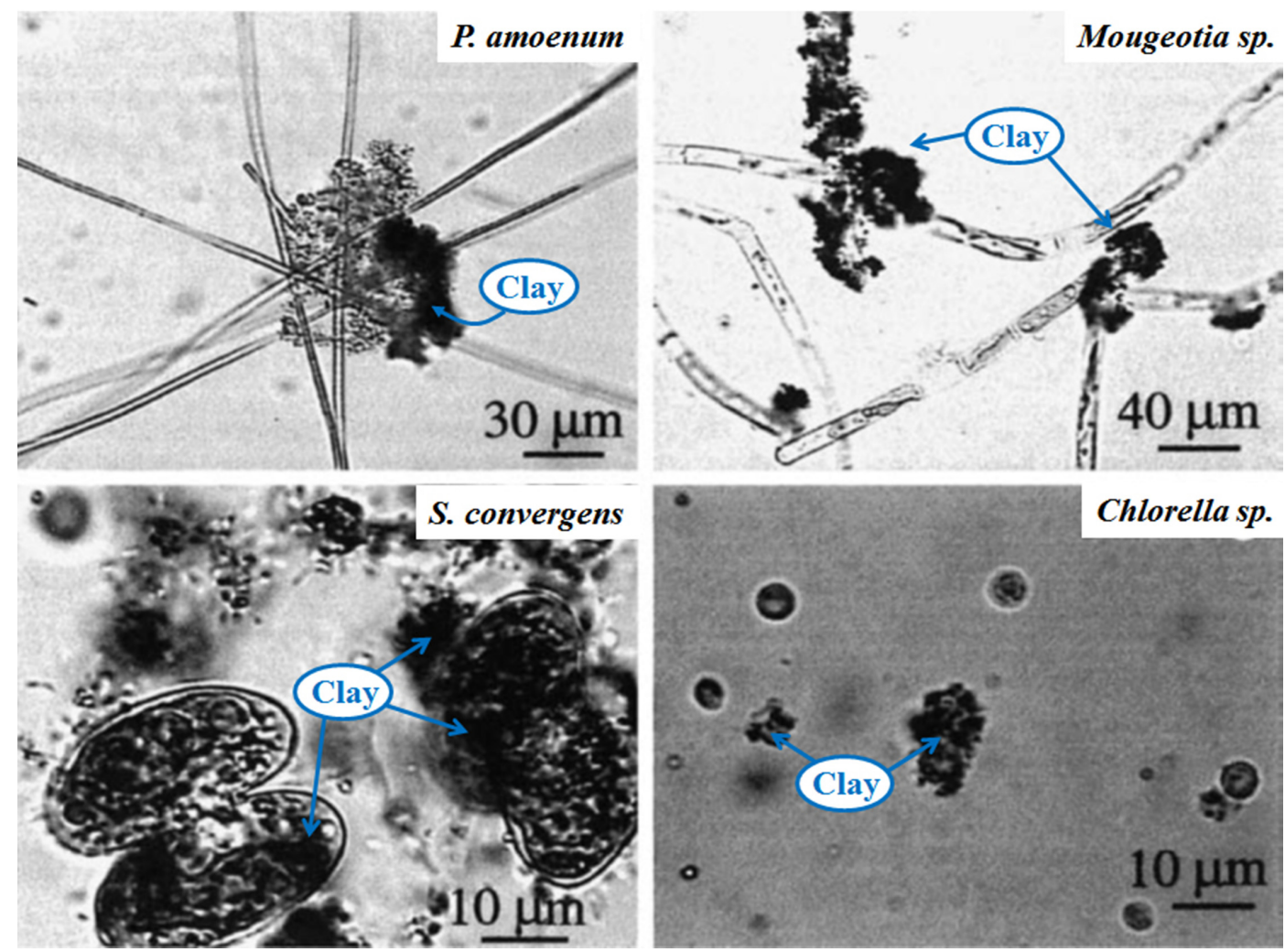

Fig. 3. Algal and clay aggregates observed for all species. [60] 
coagulate them into flocs. Other heavy metals with positive charges such as $\mathrm{Cr}^{3+}, \mathrm{Cu}^{2+}, \mathrm{Pb}^{2+}, \mathrm{Zn}^{2+}, \mathrm{Cd}^{2+}$ have a high affinity for other negatively charged algae cells. However, this adsorption capacity varies among clay types which may influence the extent of the aggregation process. The initial zeta potential of an algal solution without cells was -39.7 , but the clay (i.e. vermiculite) treated solution was fixed at 36 [66]. The suspended particles may also increase the algal cells sinking through their mutual aggregation. The formation of algae-clay aggregates depends on the number of contacts and the subsequent adhesion between algal cells and clay particles. The degree of contact will then be a function of both algae and clay concentrations, as well as of the algal morphology. The probability of this contact will depend on the clay concentration and the cell size (i.e., length, width, and surface area). The extent of the adhesion will be a function of the ionic interaction between the algae and clay as well as of the algal cell surface properties. Small sized algal cells with high surface area would require a proportionally larger amount of adhered clay particles to accelerate their sinking [60]. During the last several decades, for instance, South Korea has mainly used clay because of its cost effective advantages but clay may cause structural and functional damage in cases of long-term exposure into the human bodies because quartz chemicals, dissolving from clay, is especially related to silicosis and lung cancer [67-69].

\subsubsection{Aluminum sulfate or ferric chloride}

The coagulation process of algal blooms from polluted freshwater has used routinely $\mathrm{Al}$ and $\mathrm{Fe}$ salts (i.e., aluminum sulfate, ferric chloride) since early in the $20^{\text {th }}$ century and played a significant role in the removal of a broad range of impurities, including suspended algal cells, colloidal particles, and dissolved organic substances [70-74]. The essential mechanisms for algae removal using these salts is accomplished by charging the neutralization of negatively-charged colloids by dissolved cations and incorporating the impurities into an amorphous precipitate of metal hydroxide. A simple mechanism for the destabilization of negatively-charged particles is the specific adsorption of cationic species from solutions. The cationic $\mathrm{Al}$ and $\mathrm{Fe}$ ions of hydrolysis products neutralize or reduce the negative charge on the suspended solids containing anionic algae cells in coagulation/flocculation process. In the case of $\mathrm{Al}^{3+}$ and $\mathrm{Fe}^{3+}$, there is a primary hydration shell with six octahedrally coordinated water molecules (e.g., $\left.\mathrm{Al}\left(\mathrm{H}_{2} \mathrm{O}\right)_{6}{ }^{3+}\right)$. The hydrolysis of such ions is thought of as progressive deprotonation of water molecules in the primary hydration shell as following Eq. (1):

$$
\mathrm{Me}^{3+} \rightarrow \mathrm{Me}(\mathrm{OH})^{2+} \rightarrow \mathrm{Me}(\mathrm{OH})_{2}^{+} \rightarrow \mathrm{Me}(\mathrm{OH})_{3} \rightarrow \mathrm{Me}(\mathrm{OH})_{4}^{-}
$$

Increasing the $\mathrm{pH}$ causes the equilibria to be shifted to the right since each step involves the loss of a proton. In the case of $\mathrm{Al}$, the dominant species in the solution changes from $\mathrm{Al}^{3+}$ to $\mathrm{Al}(\mathrm{OH})_{4}^{-}$over little more than $1 \mathrm{pH}$ unit. In contrast, the corresponding change for $\mathrm{Fe}$ occurs over a range of more than $8 \mathrm{pH}$ units and intermediate species, such as $\mathrm{Fe}(\mathrm{OH})_{2}{ }^{+}$and $\mathrm{Fe}(\mathrm{OH})_{3}$, can represent more than $90 \%$ of the soluble forms at intermediate $\mathrm{pH}$ values. At $\mathrm{pH}$ values around 5-6, the suspended algae cells are negatively charged and amorphous $\mathrm{Al}$ and Fe hydroxides

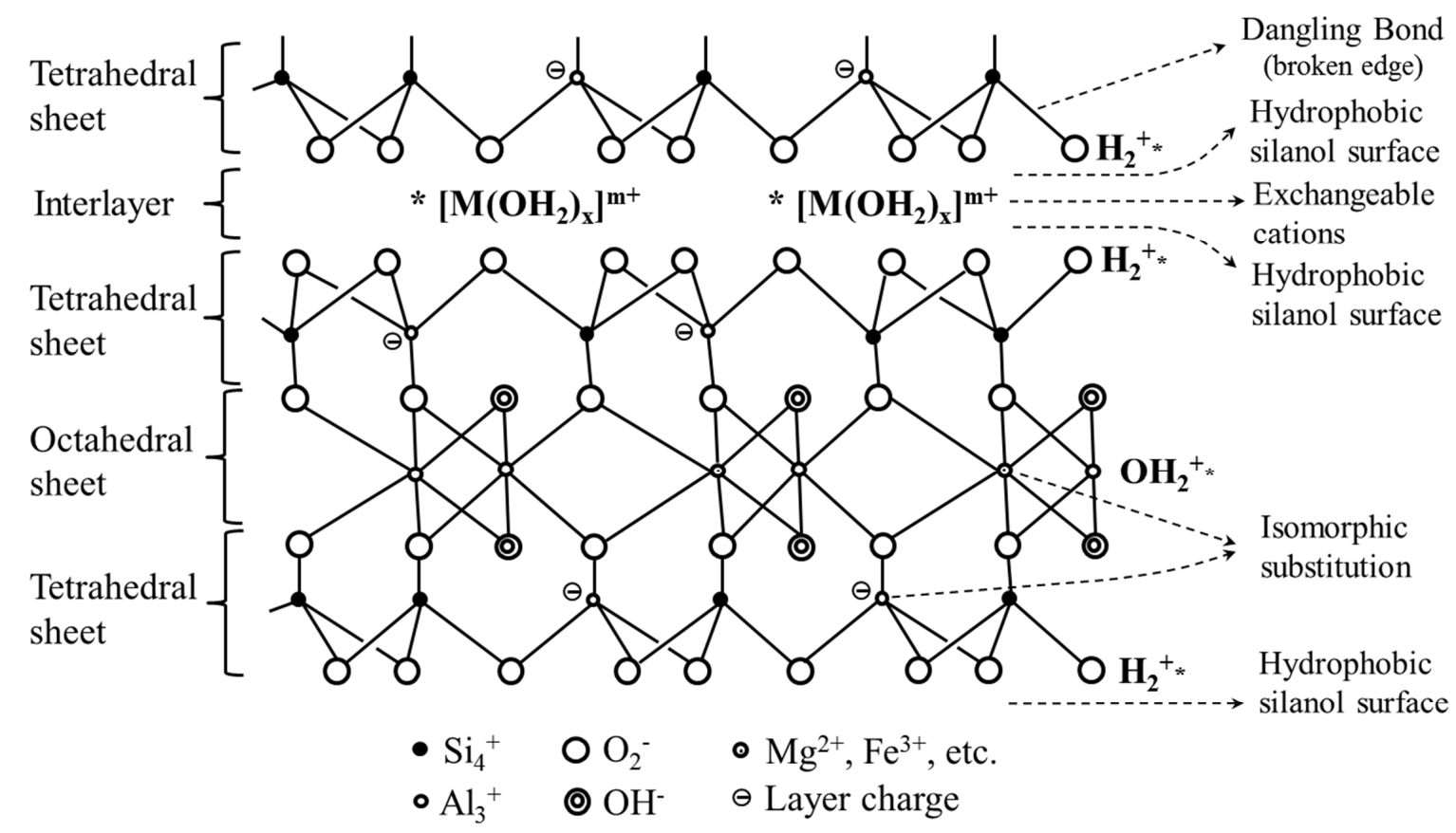

* Hydrated: Bronsted acid sites; Dehydrated: Lewis acid sites

$\left[\mathrm{M}\left(\mathrm{OH}_{2}\right)_{\mathrm{x}}\right]^{\mathrm{m}+}$ : Hydrated exchangeable cations, $\mathrm{M}=\mathrm{Na}^{+}, \mathrm{Ca}^{2+}$, etc.

Fig. 4. Schematic drawing of a representative clay mineral showing active sites. [65] 
are positively charged, which gives strong adsorption and some charge neutralization [70].

However, concerns have been raised that the use of such coagulants may increase $\mathrm{Al}$ concentrations in treated water. In Japan, the drinking water quality guideline for $\mathrm{Al}$ is $0.1 \mathrm{mg} / \mathrm{L}$, but water treatment plants usually set stricter values for finished water (e.g., $<0.05 \mathrm{mg} / \mathrm{L}$ ). Orally ingested $\mathrm{Al}$ is acutely toxic to humans and a risk factor for the onset of Alzhemer's disease in the case of long-term exposure (WHO 1998). Since the ingestion of $\mathrm{Al}$ from both food and drinking water is the most common form of human exposure, the main rout of $\mathrm{Al}$ adsorption is through the gastrointestinal tract [75-77]. In particular, maintenance of $\mathrm{Fe}$ and $\mathrm{Al}$ residuals of less than $100 \mu \mathrm{g} / \mathrm{L}$ was recommended, which was more formally accepted in the Water Quality Regulations of 1989 which mandated less than $200 \mu \mathrm{g} / \mathrm{L} \mathrm{Fe}$ or $\mathrm{Al}$ in tap water. On the other hand, concerning the water supply, coexistent chloride anions with these metal cations generate corrosion products in non-ferrous or ferrous metal which consist of storage tanks, pumps, piping, valves, and concrete. The corrosion products deteriorate water quality as well as provide habitats for microbial growth, react with disinfectant residuals [78-82].

\subsubsection{Lime}

Usually, single or multiple treatments of slake lime $\left(\mathrm{Ca}(\mathrm{OH})_{2}\right)$ and calcite $\left(\mathrm{CaCO}_{3}\right)$ are applied for removal on algal blooms and nutrients in eutrophic freshwaters. Whereas single lime treatments resulted in variable and mostly temporary changes in chlorophyll a and $\mathrm{P}$ concentrations, multiple treatments were effective in reducing both chlorophyll a and $\mathrm{P}$ concentrations over longer periods [83-85]. Lime application seems to be an economical and non-toxic tool for the restoration of surface waters because lime (calcium hydroxide) treatment does not cause any toxin release of the microcystin LR (a species of cyanobacteria). However, copper sulfate should not be used to treat toxic algal blooms in waters to be consumed by humans or animals within several weeks following treatment [86]. Cyanobacteria have been recognized as a key player in the precipitation of calcium carbonate in freshwater systems. They increase $\mathrm{pH}$ as a result of photosynthetic activity and also produce extracellular polysaccharides, which act as binding sites for $\mathrm{Ca}^{2+}$ and $\mathrm{CO}_{3}{ }^{2-}$ [87].

Oyster shells have a high potential for reuse due to their low levels of heavy metals and high level of calcium (35\%). The shell residue can potentially produce added economic value if it is transformed into raw material for other production processes because the shells contain high amounts of calcium carbonate. The calcium carbonate content of oyster shells can range from $80 \%$ to $95 \%$ [88]. After the addition of shell powder into algal freshwater, the color was dramatically changed by physicochemical reactions according to the four-step process of addition, agitation \& carbonation, coagulation, and settlement. Visible transparency of algal freshwater was also gradually converted from dark green to colorless according to the alteration of added amounts of calcined powders as shown in Fig. 5 [89]. For the total pollutant load of the algal solution, the mean removal (or reduction) efficiency of total phosphorus (T-P), total nitrogen (T-N), and chemical oxygen demand (COD) was recorded at $96.5 \%, 91.4 \%$, and $33.8 \%$, respectively [89]. The calcium hydroxide and carbonation combination in algae-containing water significantly contributed to improve water quality which is very dependent on the addition amount of calcined oyster shell powder [90].

Table 4 shows the charge transfer reaction and $25^{\circ} \mathrm{C} \operatorname{logK}$ alteration between protonic and metallic charge groups of dolomite coagulator surfaces and carboxylate, phosphate, and hydroxyl charge groups of algae surfaces. In natural water, anionic algal surface charge arises from carboxylate $(\mathrm{pH} 4-6)$, phosphate $(\mathrm{pH}$ 7-8), and hydroxyl groups ( $\mathrm{pH} 9-10)$ which become deprotonated,

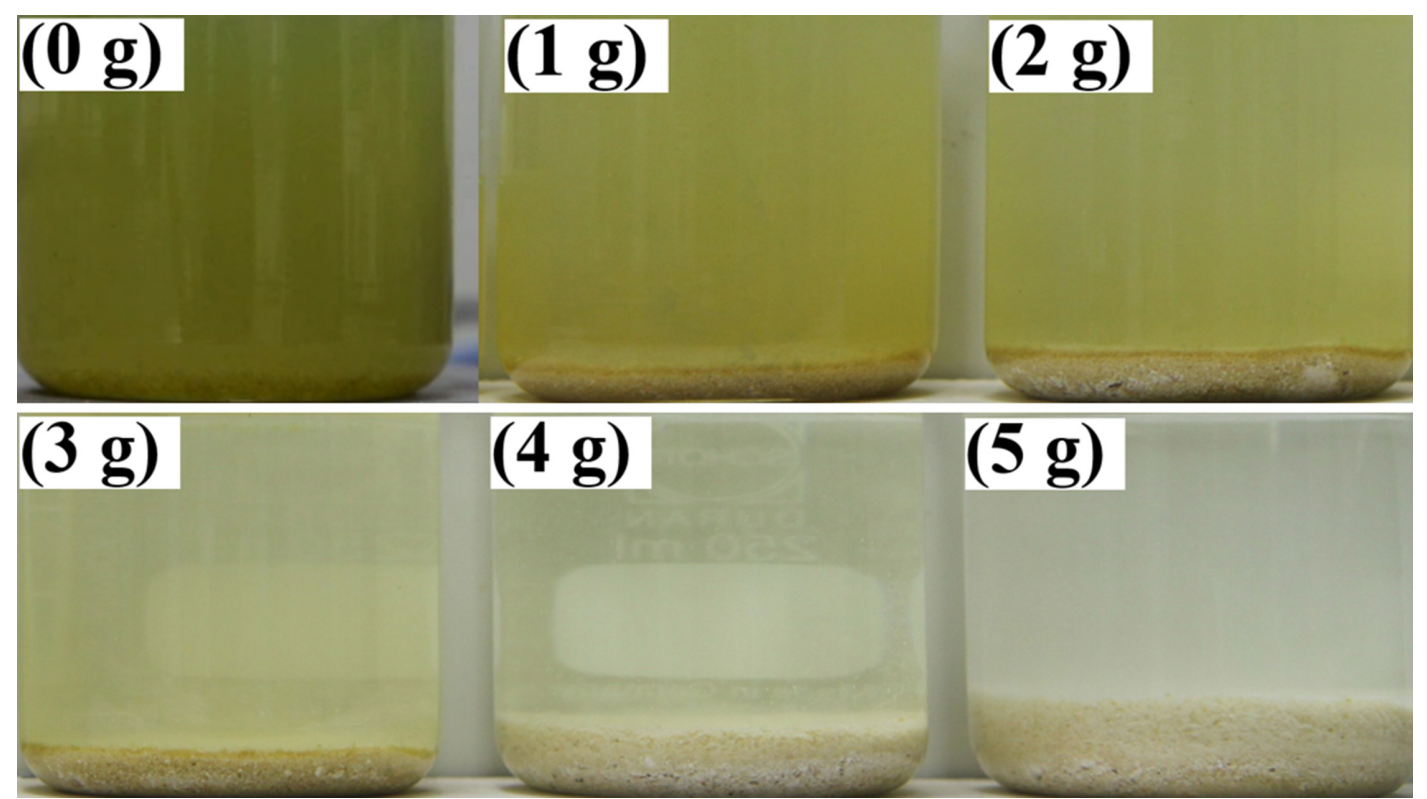

Fig. 5. The visual performance after algae coagulation process in eutrophic waters using oyster shell powder: the powder was fed from $1 \mathrm{~g}$ to $5 \mathrm{~g}$ into raw algae water of $0 \mathrm{~g}$. [89] 


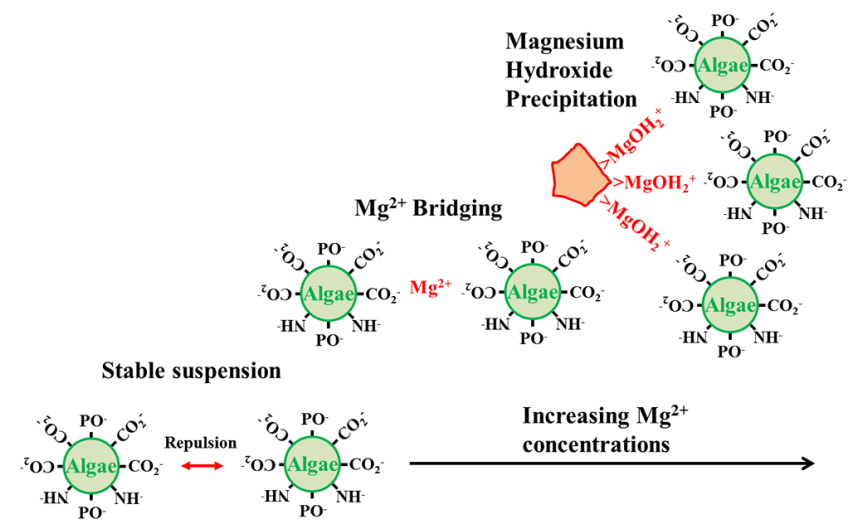

Fig. 6. A schematic diagram of algal autoflocculation after the addition of dolomite coagulator. [91]

Table 4. The Surface Charge Generation by Interaction between Algae and Dolomite [91]

\begin{tabular}{|c|c|c|}
\hline Algae & & $25^{\circ} \mathrm{C} \log \mathrm{K}$ \\
\hline 1 & $-\mathrm{COOH} \leftrightarrow-\mathrm{COO}^{-}+\mathrm{H}^{+}$ & -5.5 \\
\hline 2 & $-\mathrm{POH}^{-} \leftrightarrow-\mathrm{PO}^{2-}+\mathrm{H}^{+}$ & -7.7 \\
\hline 3 & $-\mathrm{OH}^{-} \leftrightarrow-\mathrm{O}^{-}+\mathrm{H}^{+}$ & -9.9 \\
\hline 4 & $-\mathrm{COOH}+\mathbf{C a}^{2+} \leftrightarrow-\mathrm{COO} \mathbf{C a}^{+}+\mathrm{H}^{+}$ & -3.8 \\
\hline 5 & $-\mathrm{COOH}+\mathbf{M g}^{2+} \leftrightarrow-\mathrm{COO} \mathbf{M g}^{+}+\mathrm{H}^{+}$ & -3.5 \\
\hline 6 & $-\mathrm{PO}^{2-}+\mathbf{C a}^{2+} \leftrightarrow-\mathrm{PO} \mathbf{C a}$ & 2.7 \\
\hline 7 & $-\mathrm{PO}^{2-}+\mathrm{Mg}^{2+} \leftrightarrow-\mathrm{PO} \mathbf{M g}$ & 2.9 \\
\hline
\end{tabular}

lose their $\mathrm{H}^{+}$. However, dolomite coagulator dissolves the oppositely-charged divalent cations such as $\mathrm{Ca}^{2+}$ and $\mathrm{Mg}^{2+}$ and cation bridges with adjacent algae coagulation. The solution reaches a maximum at $\mathrm{pH} \sim 11$ because of $\mathrm{Ca}(\mathrm{OH})_{2}, \mathrm{Mg}(\mathrm{OH})_{2}$ formation. $\mathrm{Mg}^{2+}$ and $\mathrm{Ca}^{2+}$ adsorption to algae might induce prompt coagulation to charge neutralization by forming bridges between individual, negatively-charged algae because the mutual repulsion of the negatively-charged algal surface helps keep algae in suspension in most natural waters. When the $\mathrm{pH}$ is raised from $\sim 8$ to 9-11, algae coagulation is also caused due to electrostatic interactions between anionic algae and divalent cations such as $\mathrm{Ca}^{2+}$ and $\mathrm{Mg}^{2+}$. Their precipitates with hydroxide or/and calcite formation are shown in Fig. 6 [91].

\subsubsection{Future outlook of coagulants}

The primary key of the successful treatment is to select available metals or chemical compounds as reasonable coagulators because every coagulant has both advantages and disadvantages as summarized in Table 5 [92, 93]. Still, the usage of coagulants is the cheapest and fastest-working method and, thus, is the most widespread across the world. However, toxic algicide (e.g., copper sulfate) can be replaced by more environmentally-friendly coagulants (e.g., aluminum sulfate, ferric chloride, and lime) although their price is higher relatively. The weak point of some coagulants is that it is still too expensive to produce them with high quality and purity. To apply industrial algae coagulants to water in reservoirs or dams, it is probably necessary to employ cost effective materials such as recycled oyster shell waste or unused dolomite kiln dust. Additional efforts will be needed to contribute to establishment of emergent solutions to algal blooms and to preserve valuable freshwater resources.

\section{Conclusions}

For sustainable freshwater resources development, conventional chemical treatment containing preoxidants, algaecide, metallic coagulators have been demonstrated extensively in the literature to efficiently remove cyanobacteria which release the toxins in eutrophic freshwater and water treatment plant. The proliferation of algal blooms in eutrophic freshwater and water treatment plant is a worldwide problem. Although the only long-term solution for this problem is the restriction of nutrient inputs into water

Table 5. A Summary of Advantages and Disadvantages of Chemical Coagulants for Management of Algal Blooms [92, 93]

\begin{tabular}{c|c|c}
\hline Method or Technique & Advantages & Disadvantages \\
\hline Copper, silver & Extremely low price & Toxicity against non-target species \\
pH influence
\end{tabular}


bodies, this method seems to be unavailable for most areas across the world because of the large financial costs. Thus, a reasonable application of techniques for cyanobacteria removal can be well founded in some cases with regards to health risks and the commercial occupancy of water bodies. This paper deals with potential coagulants to immediately improve water quality of reservoirs and plants in summer seasons through emergent chemical treatments for excessive cyanobacteria control and its residue removal. Future chemical treatment for cyanobacteria control should additionally be considered nutrient reduction of its external inputs and reduction of internal loading nutrient from released from sediments. Therefore, to successful management of the freshwater, chemical treatment performance with nutrient fixation and oxygen production ability should be additionally required to sustainable freshwater resources development and healthy aquatic animal and plants preservation.

\section{Acknowledgements}

The authors deeply appreciate the financial support from the Korea Institute of Energy Technology Evaluation and Planning (KETEP) through the ETI program, Ministry of Trade, Industry and Energy (MOTIE, Project No. 2013T100100021) and by the Algae Research and Development Project (DY000000) of Danyang-gun, Chungcheongbuk-do through the Korean Local Autonomous Entity.

\section{References}

1. Lashof DA, Ahuja DR. Relative contributions of greenhouse gas emissions to global warming. Nature 1990;344:529-531.

2. Ramanathan V, Feng Y. Air pollution, greenhouse gases and climate change: Global and regional perspectives. Atmos. Environ. 2009;43:37-50.

3. Park JY, Park GA, Kim SJ. Assessment of future climate change impact on water quality of Chungju Lake, South Korea, using WASP coupled with SWAT. J. Am. Water Resour. As. (JAWRA). 2000;49:1225-1238.

4. Scheren PAGM, Zanting HA, Lemmens AMC. Estimation of water pollution sources in Lake Victoria, East Africa: Application and elaboration of the rapid assessment methodology. J. Environ. Manage. 2000;58:235-248.

5. Stein PL. The great Sydney water crisis of 1998. Water Air Soil Poll. 2000;123:419-436.

6. Pimentel D, Berger B, Filiberto D, et al. Water resources: Agricultural and environmental issues. BioScience 2004;54:909-918.

7. Piao S, Ciais P, Huang Y, et al. The impact of climate change on water resources and agriculture in China. Nature 2010;467:43-51.

8. Frisvold GB, Konyar K. Climate change mitigation policies: Implications for agriculture and water resources. J. Contemp. Water Res. Educ. 2013;151:27-42.

9. Jury WA, Vaux H. The role of science in solving the world's emerging water problems. PNAS 2005;102:15715-15720.

10. Conley DJ, Paerl HW, Howarth RW, et al. Controlling eutrophi- cation: Nitrogen and phosphorus. Science 2009;323:1014-1015.

11. Kim B, Park J-H, Hwang G, Jun M-S, Choi K. Eutrophication of reservoirs in South Korea. Limnology 2001;2:223-229.

12. Tekile A, Kim I, Kim J. Mini-review on river eutrophication and bottom improvement techniques, with special emphasis on the Nakdong River. J. Environ. Sci. 2015;30:113-121.

13. Srivastava A, Singh S, Ahn C-Y, Oh H-M, Asthana RK. Monitoring approaches for a toxic cyanobacterial bloom. Environ. Sci. Technol. 2013;47:8999-9013.

14. Oh H-M, Lee SJ, Kim J-H, Kim H-S, Yoon BD. Seasonal variation and indirect monitoring of Microcystin concentrations in Daechung Reservoir, Korea. Appl. Environ. Microb. 2001;67: 1484-1489.

15. Smith VH, Tilman GD, Nekola JC. Eutrophication: Impacts of excess nutrient inputs on freshwater, marine, and terrestrial ecosystems. Environ. Pollut. 1999;100:179-196.

16. Verschuren D, Laird KR, Cumming BF. Rainfall and drought in equatorial East Africa during the past 1,100 years. Nature 2000;403:410-414.

17. Park J-S, Kang H-S, Lee YS, Kim M-K. Changes in the extreme daily rainfall in South Korea. Int. J. Climatol. 2011;31:2290-2299.

18. Chang H, Kwon W-T. Spatial variations of summer precipitation trends in South Korea, 1973-2005. Environ. Res. Lett. 2000;2:045012(9 page).

19. Shen Q, Zhu J, Cheng L, Zhang J, Zhang Z, Xu X. Enhanced algae removal by drinking water treatment of chlorination coupled with coagulation. Desalination 2011;271:236-240.

20. Lopez CB, Jewett EB, Dortch Q, Walton BT, Hudnell HK. Scientific assessment of freshwater harmful algal blooms. Interagency working group on harmful algal blooms, hypoxia and human health of the joint subcommittee on ocean science and technology. Washington, D.C.; 2008.

21. Dawson RM. The toxicology of Microcystins. Toxicon 1998;36: 953-962.

22. Gehringer MM, Adler L, Roberts AA, et al. Nodularin, a cyanobacterial toxin, is synthesized in planta by symbiotic Nostoc sp. ISME J. 2012;6:1834-1847.

23. Andrinolo D, Michea LF, Lagos N. Toxic effects, pharmacokinetics and clearance of saxitoxin, a component of paralytic shellfish poison (PSP), in cats. Toxicon 1999;37:447-464.

24. Puschner B, Hoff B, Tor ER. Diagonosis of anatoxin-a poisoning in dogs from North America. J. Vet. Diagn. Invest. 2008;20:89-92.

25. Hoff-Risseti C, Dörr FA, Schaker PDC, Pinto E, Werner VR, Fiorem MF. Cylindrospermopsin and saxitoxin synthetase genes in cylindrospermopsis raciborskii strains from Brazilian freshwater. PLOS ONE 1998;8:e74238.

26. Nelson SK, Knoernschild KL, Robinson FG, Schuster GS. Lipopolysaccharide affinity for titanium implant biomaterials. Toxicon 1998;36:953-962.

27. Cardellina JH, Marner F-J, Moore RE. Seaweed dermatitis: Structure of lyngbyatoxin A. Science 1979;204:193-195.

28. Jiang L, Eriksson J, Lage S, et al. Diatoms: A novel source for the Neurotoxin BMAA in aquatic environments. PLOS ONE 2014;9:e84578.

29. Hallegraeff GM. A review of harmful algal blooms and their apparent global increase. Phycologia 1993;32:79-99.

30. Davis TW, Koch F, Marcoval MA, Wilhelm SW, Gobler CJ. 
Mesozooplankton and microzooplankton grazing during Cyanobacterial blooms in the western basin of Lake Erie. Harmful Algae 2012;15:26-35.

31. Kim S-G, Rhee S-K, Ahn C-Y, et al. Determination of cyanobacterial diversity during algal blooms in Daechung Reservoir, Korea, on the basis of $c p c B A$ intergenic spacer region analysis. Appl. Environ. Microb. 2006;72:3252-3258.

32. Hitzfeld BC, Höger SJ, Dietrich DR. Cyanobacterial toxins: Removal during drinking water treatment, and human risk assessment. Environ. Health Persp. 2000;108:113-122.

33. Bláha L, Babica $P$, Maršálek B. Toxins produced in Cyanobacterial water blooms-toxicity and risks. Interdiscipl. Toxicol. 2009;2:36-41.

34. Apeldoorn ME, Egmond HP, Speijers GJA, Bakker GJI. Toxins of cyanobacteria. Mol. Nutr. Food Res. 2007;51:7-60.

35. Cheung MY, Liang S, Lee J. Toxin-producing Cyanobacteria in freshwater: A review of the problems, impact on drinking water safety, and efforts for protecting public health. J. Microbiol. 2013;51:1-10.

36. Ho JC, Michalak AM. Challenges in tracking harmful algal blooms: A synthesis of evidence from Lake Erie. J. Great Lakes Res. 2015;41:317-325.

37. Paerl HW, Fulton RS, Moisander PH, Dyble J. Harmful freshwater algal blooms, with an emphasis on Cyanobacteria. Sci. World J. 2001;1:76-113.

38. Mariani MA, Padedda BM, Kaštovský J, et al. Effects of trophic status on microcystin production and the dominance of cyanobacteria in the phytoplankton assemblage of Mediterranean reservoirs. Sci. Rep. 2015;5:17964(16 page).

39. Chorus I, Bartram J. Toxic Cyanobacteria in water: A guide for their public health consequences, monitoring and management. E\&FN Spon London, UK; 1999.

40. Coltelli P, Barsanti L, Evangelista V, Frassanito AM, Gualtieri P. Water monitoring: Automated and real time identification and classification of algae using digital microscopy. Environ. Sci. Proc. Imp. 2014;16:2656-2665.

41. Dybas CL. Harmful algal Blooms: Biosensors provide new ways of detecting and monitoring growing threat in coastal waters. BioScience 2003;53:918-923.

42. Reichwaldt ES, Ghadouani A. Effects of rainfall patterns on toxic Cyanobacterial blooms in a changing climate: Between simplistic scenarios and complex dynamics. Water Res. 2012;46:1372-1393.

43. Hoeger SJ, Hitzfeld BC, Dietrich ER. Occurrence and elimination of cyanobacterial toxins in drinking water treatment plants. Toxicol. Appl. Pharm. 2005;203:231-242.

44. Ebeling JM, Sibrell PL, Ogden SR, Summerfelt ST. Evaluation of chemical coagulation-flocculation aids for the removal of suspended solids and phosphorus from intensive recirculating aquaculture effluent discharge. Aquacult. Eng. 2003;29:23-42.

45. Junli H, Li W, Nenqi R, Li LX, Fun SR, Guanle Y. Disinfection effect of chlorine dioxide on viruses, algae and animal planktons in water. Water Res. 1997;31:455-460.

46. Xie P, Ma J, Fang J, et al. Comparison of permanganate preoxidation and preozonation on algae containing water: Cell integrity, characteristics, and chlorinated disinfection byproduct formation. Environ. Sci. Technol. 2013;47:14051-14061.
47. Chen J-J, Yeh H-H, Tseng I-C. Potassium permanganate as an alternative preoxidant for enhancing algal coagulation-pilot and bench scale studies. Environ. Technol. 2008;29:721-729.

48. Chen J-J, Yeh H-H. The mechanisms of potassium permanganate on algae removal. Water Res. 2005;39:4420-4428.

49. Shen Q, Zhu J, Cheng L, Zhang J, Zhang Z, Xu X. Enhanced algae removal by drinking water treatment of chlorination coupled with coagulation. Desalination 2011;271:236-240.

50. Plummer JD, Edzwald JK. Effect of ozone on algae as precursors for trihalomethane and haloacetic acid production. Envion. Sci. Technol. 2001;35:3661-3668.

51. Moore GT, Kellerman KF. A method of destroying or preventing the growth of algae and certain pathogenic bacteria in water supplies. Bulletin 64:15-44, Bureau of Plant Industry, U.S. Department of Agriculture; 1904.

52. Nichols MS, Henkel T, Mcnaul D. Copper in lake muds from lakes of the Madison area. Trans. Wis. Acad. Sci. 1946;38:333-350.

53. Hasler AD. Antibiotic aspects of copper treatment of lakes. Trans. Wis. Acad. Sci. Arts Lett. 1947;39:97-103.

54. Kenneth MM, Harold LC. The biological effect of copper sulphate treatment on lake ecology. Trans. Wis. Acad. Sci. Arts Lett. 1952;41:177-187.

55. Elder JF, Horne AJ. Copper cycles and $\mathrm{CuSO}_{4}$ algicidal capacity in two California Lakes. Envion. Manag. 1978;2:17-30.

56. Song L, Marsh TL, Voice TC, Long DT. Loss of seasonal variability in a Lake resulting from copper sulfate algaecide treatment. Phys. Chem. Earth 2011;36:430-435.

57. Jeune A-HL, Charpin M, Deluchat V, et al. Effect of copper sulphate treatment on natural phytoplanktonic communities. Aquat. Toxicol. 2006;80:267-280.

58. Beaulieu SE, Sengco MR, Anderson DM. Using clay to control harmful algal blooms: Deposition and resuspension of clay/algal flocs. Harmful Algae 2005;4:123-138.

59. Han MY, Kim W. A theoretical consideration of algae removal with clays. Microchem. J. 2001;68:157-161.

60. Guenther M, Bozelli R. Factors influencing algae-clay aggregation. Hydrobiologia 2004;523:217-223.

61. Sengco MR, Anderson DM. Controlling harmful algal blooms through clay flocculation. J. Eukaryot. Microbiol. 2004;51:169-172.

62. Park C, Kang M. Impact assessment of turbidity water caused clays on algae growth. J. Eng. Geol. 2006;16:403-409.

63. Gaudette HE, Eades JL, Grim RE. The nature of illite. Clays Clay Miner. 1964;13:33-48.

64. Hunziker JC, Frey M, Clauer N, et al. The evolution of illite to muscovite: Mineralogical and isotopic data from the Glarus Alps, Switzerland. Contrib. Mineral. Petr. 1986;92:157-180.

65. Zhou CH, Keeling J. Fundamental and applied research on clay minerals: From climate and environment to nanotechnology. Appl. Clay Sci. 2013;74:3-9.

66. Miao C, Tang Y, Zhang H, Wu Z, Wang X. Harmful algae blooms removal from fresh water with modified vermiculite. Environ. Technol. 2014;35:340-346.

67. Williams RB. Bentonite, kaolin and selected clay minerals. Environ. Health Criteria 2005;15:1-196.

68. Stauber JL. Toxicity testing of modified clay leachates using freshwater organisms. CSIRO Center for Advanced Analytical Chemistry Energy Technology, Report No: ET/IR267R; March 
2000.

69. Lewis MA, Dantin DD, Walker CC, Kurtz JC, Greene RM. Toxicity of clay flocculation of the toxic dinoflagellate, Karenia brevis, to estuarine invertebrates and fish. Harmful Algae 2003;2:235-246.

70. Gregory J, Duan J. Hydrolyzing metal salts as coagulants. Pure Appl. Chem. 2001;73:2017-2026.

71. Godward MBE. The iron alum acetocarmine method for algae. Nature 1948;161:203-203.

72. Dawah A, Soliman A, Abomohra AE-F, Battah M, Anees D. Influence of alum on Cyanobacterial blooms and water quality of earthen fish ponds. Environ. Sci. Pollut. Res. 2015;22: 16502-16513.

73. Wyatt NB. Gloe LM, Brady PV, et al. Critical conditions for ferric chloride-induced flocculation of freshwater algae. Biotechnol. Bioeng. 2012;109:493-501.

74. Chen L, Li P, Liu Z, Jiao Q. The released polysaccharide of the cyanobacterium Aphanothece halophytica inhibits flocculation of the alga with ferric chloride. J. Appl. Phycol. 2009;21:327-331.

75. Kimura M, Matsui Y, Kondo K, Ishikawa TB, Matsushita T, Shirasaki N. Minimizing residual aluminum concentration in treated water by tailoring properties of polyaluminum coagulants. Water Res. 2013;47:2075-2084.

76. Niquette P, Monette F, Azzouz A, Hausler R. Impacts of substituting aluminum-based coagulants in drinking water treatment. Water Qual. Res. J. Canada 2004;39:303-310.

77. Campbell A, Hamai D, Bondy SC. Differential toxicity of aluminum salts in human cell lines of neural origin: Implications for neurodegeneration. NeuroToxicology 2001;22:63-71.

78. Edwards M, Scardina P, McNeill LS. Enhanced coagulation impacts on water treatment plant infrastructure. American Water Works Association (AWWA) Research Foundation, Denver, CO; 2004.

79. Huh JH, Oh EJ, Cho JH. Corrosion characteristics of electrochemically prepared doped polyaniline films in acidic chloride environments. Syn. Met. 2005;153:13-16.

80. Alfantazi AM, Ahmed TM, Tromans D. Corrosion behavior of copper alloys in chloride media. Mater. Design 2009;30:
2425-2430.

81. Miyazato S-I, Otsuki N. Steel corrosion induced by chloride or carbonation in mortar with bending cracks or joints. J. $A d v$. Concr. Technol. 2010;8:135-144.

82. Slavíčková K, Grünwald A, Št'astný B. Monitoring of the corrosion of pipes used for the drinking water treatment and supply. Civil Eng. Archit. 2013;1:61-65.

83. Prepas EE, Pinel-Alloul B, Chambers PA, et al. Lime treatment and its effects on the chemistry and biota of hardwater eutrophic lakes. Freshwater Biol. 2001;46:1049-1060.

84. Prepas EE, Murphy TP, Crosby JM, et al. Reduction of phosphorus and chlorophyll a concentrations following $\mathrm{CaCO}_{3}$ and $\mathrm{Ca}(\mathrm{OH})_{2}$ additions to hypereutrophic Figure Eight Lake, Alberta. Envion. Sci. Technol. 1990;24:1252-1258.

85. Huh J-H, Choi Y-H, Ahn JW. Limestone particles for algae treatment (in Korean). Ceramist 2015;18:5-13.

86. Kenefick SL, Hrudey SE, Peterson HG, Prepas EE. Toxin release from Microcystis aeruginosa after chemical treatment. Water Sci. Technol. 1993;27:433-440.

87. Dittrich M, Sibler S. Calcium carbonate precipitation by cyanobacterial polysaccharides. Geol. Soc. London Spec. Publ. 2010;336:51-63.

88. Alvarenga RAFD, Galindro BM, Helpa CDF, Soares SR. The recycling of oyster shells: An environmental analysis using life cycle assessment. J. Environ. Manag. 2012;106:102-109.

89. Huh J-H, Choi Y-H, Lee H-J, et al. The use of oyster powders for water quality improvement of lakes by algal blooms removal. J. Korean Ceram. Soc. 2016;53:1-6.

90. Huh J-H, Choi Y-H, Ramakrishna C, Cheong SH, Ahn J-W. Use of calcined oyster shell powder as a $\mathrm{CO}_{2}$ adsorbent in algae-containing water. J. Korean Ceram. Soc. 2016;53:429-434.

91. Brady PV, Pohl PI, Hewson JC. A coordination chemistry model of algal autoflocculation. Algal Res. 2014;5:226-230.

92. Jančula D, Maršálek B. Critical review of actually available chemical compounds for prevention and management of cyanobacterial blooms. Chemosphere 2011;85:1415-1422.

93. Ghernaout B, Ghernaout D, Saiba A. Algae and Cyanotoxins removal by coagulation/flocculation: A review. Desalin. Water Treat. 2010;20:133-143. 